\title{
The Global Age: From a Sceptical South to a Fearful North
}

\author{
Jagdish Bhagwati \\ 1. INTRODUCTION: PREBISCH AND UNCTAD
}

II $T$ is an honour and a pleasure to give the Raul Prebisch Lecture. The honour corys fromi recalling an exceptional man. Prebisch was an eminent scholar and a prominent actor on the policy stage. The honour is the greater because of where the lecture is given. 'The emergence of the new South Africa under Prosident Mandele, wedded to the rule of law and a commitment to producing racial and othic harmony in a world pulling in more dissonant and destructive directions, has been a ray of hope for all of mankind. But it is not geography alove that lends added honour to my lecture. History does as well. Put within the UNCTAD iX programme it insvitably recalls the glory of UNCTAD under the able leaderstip of Raul Prebisch at the creation.

My homour goes also with pleasue. The pleasure is immediate and personal. For, as it happens, my very first policy experience on ihe international stage was at UNCTAO over three decades ago, when Raul Prebisch was the first Secretary Gencral, and I was invited, a young Professor of International Trade in Delhi, at the tender age of 29 to serve on an Expert Group preparing a report on trade liberalisation by and among developing comntrics. I recall this also because it has many aspects that bear on Rau! Prebisch and on UNCTAD itself. The Expert Group, of what we would today call an Eminent Persons' Group in our age of vanity, was chosen by UNCTAD, not nominated by governments, so it had the independence to chase ideas unconstrained by govemmental directives. As a result, Raul Prebisch, and UNCTAD under him, were characterised by intellectual curiosity and by a willingness to examine, cross-examine and reject all and even Prebisch's own views. The institution was ahead of the curve: seizing leadership on issues and prorouncing on them with the best intellectual resources then available.

JAGDEH BHACWATi is Arthur Lehmar Rrofossor of Eronomics and Folitical Science at Columbia Unversity. This pape is an abbreviated text of the Raul Probisch Lecture given at UNCTAO IX in Johanneshurg on 29 April 1936. 
In fact, let me recall that issues such as the international migration of skilled manpower and its economic implications for the rights and obligations of migrants, and of the countries of origin and destination, the questions raised by intellectual property protection in a world with growing importance of technology, and trade issues such as tariff escalation and value added protection (now known as effective protection) were first recognised and discussed within UNCTAD and became matters for further analytical contribution in the academe. A personal reminiscence again illustrates the point I am making: it concerns the fact that UNCTAD raised the question of services in world trade long before it got on to the GATT. When, some years ago. I was invited to give the annual Geneva Lecture of the International Insurance Association, I chose the topic of GATT and Trade in Services. Dr Giavini, Secretary of the Association, told me later that when he had told the Chairman of his Council, a leader in Britain's insurance industry and member of the House of Lords, about my subject, he had asked: 'Hmmm; GATT; What is it? Some kind of UNCTAD?'

This is hard to appreciate as the memory of this institution and of Prebisch has faded in the OECD countries, and it has become comnonplace in some influential quarters to think of UNCTAD as if it was instead UNWASHED and UNKEMPT. The irony is that, just as this unfortunate view has gained ground, the academic evaluation of the role of more respected agencies, such as the World Bank, as the fountainhead of new ideas has become sceptical. Thus, a much-cited recent study, co-authored by the macroeconornist Michael Gavin, now the principal economist with the Inter-American Development Bank, and one of today's most distinguished young developmental economists Dani Rodrik (who, I might add, started out his career at UNCTAD), has argued that the social rate of return in terms of innovative ideas on the World Bank's massive expenditure to date on research has been negligible.'

Nonetheless, there is no smoke without firc. UNCTAD did indeed allow the early openness and stress on expertise to lapse progressively. It also increasingly made the mistake of assuming that intellectually weak argumentation by radical economists on the fringe, just because it was outside the mainstream, was therefore also the appropriate way to think about the developing countries: a non sequitur which would be fatal to its health. Instead, UNCTAD should have exploited the enormous diversity of views within the mainstream itself, drawing on a range of

\footnotetext{
'See Gavin and Rodrik (1995). These authors do say. however. that the World Bank has done a good job of disseminating (as against creating) good ideas, an area where UNCTAD took the back seat over time. In accounting for the latter, the willingness of the World Bank to draw on mainstream economists and their increasing neglect over the years by UNCTAD (as stated below in the text) must be considered the chief culprit. (Of course, I ani describing only the central thrust of each institution's merits and demerits in regard to using and disseminating good ideas. There are important exceptions, especially in regard to UNCIAD's recent work, particularly on so-called 'trade and' issues, such as the interface of trade and the environinent.)
} 
reputed economists as Prebisch did, to advance the intellectual debate in ways that conld have complemented by counterpoint the orthodoxies prevailing in other agencies with agendas defined by their own composition and interests.

The era that lies ahead inder Mr Ricupero's leadership is now poised to return UNClAD to that ambitious role and creative mode that characterised the Prebisch era, as nuty of us 'friends of UNCTAD' fondly recall it. But the definition of that role camnot be that JNCTAD would reflect a particularistic and unique 'developing country viewpont' as often in the past. Paradoxically, that approach, if it ever madk any sense earlier, certainly makes no sense today, for two contrasting but complementary reasons.

The developing countries are now too diverse in their economic and political circumstance and context to make generally possible a unified viewpoint as 'theirs' (i.t. that of the 'South'). This changed reality surely played a principal role in the rapid demise in the $1970 \mathrm{~s}$ of the Global Negotiations that wore predicated on the premise of North-South confrontation. ${ }^{2}$

At the same time, the carlier notion that the developing countries are divided from the developed countries (the "North") in terms of their economics, justifying Special and Differential Treatment at the GATT etc., has yielded to the view that economics is aniversal, and that ideas and policies such as trade protection, extensive regulation by a burtaucratised state, generic restraints on inward foreign investment and the stifing of markets generally are bad for everyone, whether developing or developed.

In fact, the universilism extends to politics as well, and not just to economics today. Thus, the notion that democracy is fine for the developed countries, but that development requires authoriarian siructures of govemance, is no longer considered plausible. Since we mes in Solth Africa, which is a meritorious example of a functioning demorracy today as India has been in the postwar decades, let me dwell on this important issue a trifle longer.

I suspect that the defunct claims in support of authoritarianism for the developing comties were a result of the prevalent style of economic thinking when the postwar period of planning began. It was argued, following the influental model of Harrod and Domar, then the rate of growth depends on what you invest and what you get cut of it by way of increased income. It thus depends on the savings (and irivestment) rate as well as on the investment (i.c. "marginal capital') to output ratio. If one treated the marginal capital-output ratio as more or less a technological parameter, then all policy action was concentrated on

\footnotetext{
So did the recomntion that 'commodity power', based on an extension of OPEC's success to several other commodities. was an illusion, even though it had been embraced as a new phenontuon iedefining the relationship between developing and developed countries by shrewd politicians such as Henry Kissinger and by policy intellectuals such as Fred Bergsten, prior to the Nairybi UNCTAD for a fuller analysis, see Bhagwatj and Ruggie (1984. Ch. 2),

${ }^{3}$ I have considered this questioni in dopth in Bhaguati (1995).
} 
raising the average savings rate to increase investment. and hence the growth rate. Moreover, if public sector saving was considered to be the principal agent for raising the savings ratio, as it was at the time, then it was evident that the authoritarian states would be at an advantage over democracies. But, of course, the reality turned out to be otherwise. The variations in growth performance across countries have tended to reflect not just differcnces in rates of investment, but also dramatic differences in the marginal capital-output ratio. The latter, in turn, reflects the policy framework and its effects on the efficient use of resources. ${ }^{4}$ Again, I would argue that the policy framework relevant here includes incentives and democratic processes that both enable and motivate effective participation by the citizenry in the growing economy. And recent arguments further suggest that the combination of economic markets and political democracy is unbeatable as a prescription for sustained, long-run growth.

So, confronted by this new universalism, the intellectual niche that UNCTAD can occupy with success must be embedded within it, instead of being built on the exceptionalism of the developing countries. Within this broad universalism. UNCTAD can nonetheless advance perspectives, informed by scholarly research, that better reflect the interests of the developing countries that other institutions are unlikely to offer if past experience and present realities are a guide. 5

UNCTAD can make its unique contribution to 'tade and development', its original terms of reference and its rationale at the creation in several ways, such as the tasks that Mr Ricupero has been outlining recentiy: for examplic, the provision of technical assistance in trade matters to developing countries that lack the capabilities to operate in the increasingly complex trading regime today. ${ }^{6}$ But it can do so also by examining these fears of the developed countries, seeking to lay them to rest where they are exaggerated and unwarranted, while also probing the rationale and the wisdom of the measures (such as the proposed Social Clause in the WTO) that these fears have prompted, exposing them to unbiased. scholarly and apolitical scrutiny.

\footnotetext{
${ }^{4}$ We should not forget that the policy fr...... in ark aftects the rate of investment as well. In fact, this played a central rolc in my vicw in accounting for East Asia's phenomenal growth in the postwar period, as argued in Bhagwati (1996).

One example miglit illustrate, lest you might think that 1 am putting up a straw man. When the quesion of intellectual property protection (IPP) was being extensively debated at the GATT, the overwhelming view in the scholatly community was that the IPP being demanded in Geneva was being pushed by lobbies in the developed countries to the point where it was far too high. But, to my knowledge. this predominant scholarly view was not forcefully adopted and disseminated by the cading international agencies, whether the OECD or the World Bank. It is doubtul that Pretrisch's UNCTAD would have remained so indifferent, abandoning both good econonics and the interests of the devcloping countries, if it had been confronting the IPP question instead. Indecd, the GATT must be complimented for having permitted its staff to pursue precisely the seeptical research, even if in a very small way, that others were unable or unwilling to provide.

"The requirements here are cnormous, especially as legal tine print has invaded everything concerning trade to a degree where cven large and highly-skilled developing countries such as India are handicapped by their lack of trade-legal expertise in looking out for their interests.
} 
UNCIAD's history and mission, as an institution focused on the developing countrics' problems, should ensure that its perspectives will complement those of the OECD. whose history and mission focus its research and agenda so as to reflect more closely the political concerns and the economic interests of the doveleped countries that constitute its membership ${ }^{7}$ Both should serve to inform ard assict, in friendly cooperation, the WTO as it prepares, under Mr Ruggiero's leadershin, to extend and strengthen the world trading regime to meet the challenges of the Global Age as we enter the 2 ist contary.

So, Itum to the theme of this lecture: the Global Age and its consequences. I will begin with my central obervation and the organising principle of my analysis: the irony of the role reversal that has occured between the developing and the developed economies on falts of integration into the global economy. 1 wil! highlight the fact that these fears of the developed countries are heavily, and destrictively, focused on integration with the developing countries, just as the feass of the developing countries in the postwar decades were focused symmetrically on the imagined dangers of integrating with the developed countries.

I will then argue shat these fears are, at best, exaggerated and, at worst, illinformed. In addition. I will suggest that the current, fear-fed dernands in the major developed countries for changes in the rules ard regimes that govern the world economy are mach ton often ill designed. It is time for the leaders of the developed world to dofuse these fearc and, where the fears have some basis, to act less like polticians lazily compromising with lobbies to accept whatever demands they moke, and then forcing the international adoption of their proposed harmful changes in the world economy, and instead to act more like statesmen who recognise these pressures but deflect them into more creative proposals that strengthen, wher than weaken, the architcoture of the world economic regime.

\footnotetext{
${ }^{7}$ This vicw contrasts, I suspece with that of sorme OECD governments, chictly the United States. wich would rather eirasculate the research capabinites of UNCTAD (and for that matter, of the WTO) and concentrate them exclusively in the rwo Bretton Woods institutions, the IME and the Worlit Pank. The research leadcrstip of these two institutions, one might observe without caricature has been jealously guarded by tho leating developed countries

${ }^{*}$ Indecd the redelinition of the UNCTAD role also inplics a close working relationship between it and the WTO, putting behind the two institutions the indifference, even hostility dimes, that matred the rolationstip in the sary days when the GATI was considered to be the playgound of the wealther nations and UNCTAD the champion of the poorer ones. (The witricism went that the UNCTAD Secretariat was deliberately sited 50 as to obscure the GATT's vicw of the lake from its earlice location, in an ultimate aci of defiance!)

As the YTO, with the developing countries active players within its own new whiversalism, now seeks to colarge its minisule institutional research capability to support its creative elforts on behalf of the multilateral trading system (in which efforis we can onty support), it can also reach out for research soperation with agencies such as UVCTAD on issues of comenon concern. Again, under the kaderstip of Mr Ricupero and Mr Kuggicto, signs of such conperation can already be founst.
} 


\section{THE GLOBAL AGE: THE IRONIC ROLE REVERSAL}

The dominant feature of the world economy is its increasing globalisation and the growing fear of its consequences in the developed countries. The latter, a consequence of actual globalisation or integration into the world economy on several dimensions, is in sharp contrast to the warm embrace of the Global Age by the policy makers in a large number of the developing countries.

It also represents a marked reversal of attitudes in the two sets of countries from the time of Prebisch. At that time, in the early postwar decades, the developing countries were sceptical, even afraid, of potential globalisation, shying away from such international integration, while the developed countries were into the Liberal International Economic Order, tearing down trade barriers in successive GATT Rounds, liberalising direct investment flows (despite the occasional protests such as that of $\mathrm{Mr}$ Servan-Schreiber of France on The American (hallenge) and forging ahead on securing currency convertibility.

The developing countries' fear of global integration is best evoked by a celebrated Latin American formulation of the time: "integration into the world economy leads to disintegration of the national economy'. In place of the agreeable conclusion of conventional economics that international trade, investment, etc. were mutual gain, benign-impact phenomena, constituting an opportunity rather than a peril, the developing country intellectuals and policy makers, for the most part, subscribed to a zero-sum view of the integration process which involved what Prebisch called the Centre and the Periphery. Thus, they either had a malign-impact view of globalisation, or they believed in malignintent paradigms, where trade and aid were regarded as instruments of neocolonialism.

Today, those attitudes have yielded to the benign-impact views, as developing countries, one after another, have changed their policies to seek fuller integration into the global economy. Three examples should suffice to illustrate. President Cardoso, the dependencia theorist of yesteryear, is today's mastermind of Brazil's economic reforms that take her ever more into the global economy. President Salinas led Mexico into NAFTA, turning on its head former President Porfirio Diaz's famous dictum: 'Poor Mexico: how far from God and how near the United States!' Finally, even India, mired in inward-oriented policies for over a quarter of a century, has begun a deliberate and systemic change of gear to move its economy into the Global Age. ${ }^{9}$

\footnotetext{
${ }^{4}$ The reasons why the developing countries have moved to reforms are the subject of extensive analysis by economists today. Among these reasons, the value of example (i.e. the success of other nations following different policies) and of failure (of one's own policies) is certainly an important factor. In addition, we must reckon with the effect of pro-reform aid conditionality, although the impact of one's policy failures will play a role in turn since such failures are what drive countries into the Bretton Woods institutions that enforce such conditionality.
} 
But. as globolsaton has procoded apace on virtually every dimension of international interaction, whetber trade or direct investment, or capital flows or migration, the developed coumiries have witnessed growing alarm froun their citions over its implications for a vartety of issuen: real wages of workers, economis secrity, poltical asmomy and democray, the ability to maintain high labour standerds, etc.

That fintentisan has acelerated is hard to dispute. This, in both world trade and investment there ane grester trassactions and filows, often even when adjusted for increased nationd incomos, sugsessing that the conomic activities of nations are inosengly in the global arena. But evon this indes misteads, at least for the

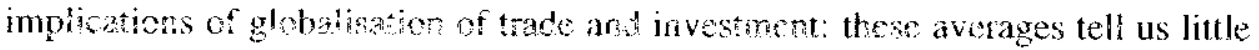
about the 'margin' and abont what global compotion offers in terms of both oprorunity and 'vulrerability' to prodecens.

Lat mo bog by duathe the charging realities on trade flows, as some of the pincipal fors of the doveloped courencs today and their unfortmate demands follow pronisely fromi this phemomenco. Trade in both goods and services has continued to grow faster relative to raticnal incones throgghout the postwar period, despite the Con indeced macro crisis in the 1970 s and the deflation during the early 1980 . The successive rounds of reciprocal tariff and NTB redrctions under GAT auspices have been a major contributory factor that the Uruguay Round will sirengthen as it brings freer matkets to new sectors, while opening the doors wider in the old sectors.

But more can be said. In somo respecs, the rise in the shane of trade to GNP has mostly restored world trade to is prewar situation. Thus, for the United States the share of merchandise trade in natonal income was 6.1 per cent in 1913 and 7 per cent in 1900 the difference is pot compelling. But the shares were 3.6 per cent in 1950 ard 3.8 per cent in 1960 , so the perceptions today have been defined arimoubedly by the prowar rise, not by the fact that this rise is more or less back to 'romal levels interupted by the period between the Great Depression and the end of the Second World War. ${ }^{10}$

More perimenty, this shere hides the important reality that the share of trade within the higely tradeable mechandise and primary goods sectors has grown pereptibly compared to both the prewas and the nmediate postwar levels. In fact, by the 1980 s there was a vast increase in the exposere of tradeable industries to intemational competition. a situation that was more tute of primary industries in the prewa period now characterises mot manufactures today. It is not true that these shan continas to increase explosively; in fact rosearch suggests that they may have sabitised iñ the las deceds. Buit the reality of substantial exposure to intemation competition, the fact that few industries today can pretend that they are prof irom intemational competition, and conscicusnoss thereof in defining

\footnotetext{
"Sec Lowin (1908).
} 
issues and demands for governmental action, are major factors that we ignore at our peril.

Indeed, the increased integration of the world's financial markets and the increased transnationalisation of production by multinationals, both phenomena of globalisation that have run a parallel as well as a supportive course, have combined with the convergence in technological ability and know-how among the OECD countries to make competition amoing firms across nations fairly fierce. Firms in different countries can access similar technologies, borrow at similar interest rates and produce where it pays a little more to do so in a manner which was still difficult a decade ago. The margins of competitive advantage have therefore become thinner: a small shift in costs somewher: can now be deadly to your competitiveness. "In the old days, we used to call such industries 'footloose': the ability to hold on to them was fragile, as the 'buffer' or margin of competitive advantage was not substantial. But few considered such industrics to be the norm. Today, because of the factors I have mentioned. they are. I have called this the phenomenon of kaleidoscopic comparative advantage, a concept that gives meaning to the notion that globalisation of the world economy has led to fierce competition: slight shifts in costs can now lead to shifting comparative advantage, which is therefore increasingly volatile.

This argument has the advantage of contributing to the explanation, in a unified way, of three important phenomena that are iri evidence today as the source of the fears of the Global Age in the developed countries.

(i) The vulncrability of one's competitiveness that has so arisen, reflecting the newly volatile, kaleidoscopic comparative advantage means that firms are increasingly tempted to look over their foreign rivals' shoulders to see if differences in their domestic policies and institutions are giving them that fatal extra edge in competition which then amounts to unfair trade. The proliferation of 'fair trade' demands in the developed coutitries to harmonise domestic institutions and policies as prerequisites for free trade among trading nations reflects, among other lesser reasons, this growing perception of kalcidoscopic comparative advantage. ${ }^{12}$

(ii) The globalisation-led kaleidoscopic comparative advantage also reinforces, albeit in a small way, the substantial sense of economic insecurity

\footnotetext{
"Economists call this a 'knife-edge' phenomenon, as in the case of Ricardian comparative advantage. where a small shift in comparative advantage can lead to a sutstantial shift in production.

${ }_{12}$ These other reasons include inoral ones, as represented by humari rights NGOs which seek to stamp out domestic differences in conformity to universal human rights notions. I have discussed the different philosophical, econoinic, structural and political fictors variously underlying the many demands for harmonisation that are breaking out woday in Bhagwati and Huder (1996, Ch. 1), resulting from a research project under the auspices of the American Society of International Law.
} 
now overtaking the citizens of the developed contries: for it must add to the labou hurnover that reflects the increased rate of job displacements and a distinct (though simall) reduction in the permarence of jobs that now afflicts even the white-collar workers.

(iii) In the same fashion, it likely contributes in some small way to the decline in real wages of the unskilled. For increased labour tumover must mean that workers stay less on average on the job so that they acquire less cn the-job training, and employers also give them less of it as they expect the workers to move on, this flattening their lifetime earaings curve: just as a rolling stone gathers no moss, a moving worker gains few skills and earns less increments in wages $^{13}$

Of conse, this rise of fierce competition ard the attendant sense of economic vulnerability relate to the globalisation itself, and are not focused on integration with the drveloping countries as the source of the difficulties in the developed comtrics. But this is not twe if I were to complete the sketch of the developed countries' fears of the Global Age by noting that they have been accentuated by the fact that intemational capital and labour flows, vis-à-vis the developing conntries in particular, are also seen as increasingly compounding the problems posed by the expanded trade shares. l, et me just cutline the principal themes.

Dircet foreign invesiment (DFi) has expanded greatly, with North-North DFI during the $1980 \mathrm{~s}$ becoming as impontant as North-South DFI, a phenomenon noticeable in the ase of Japam, especially as her DFi parially replaced her exports to the EU aid the US in response to protectionist threats in specific securs such as antomobites, and then later in response to the rising yen. While the Servar-Schrether variety of angush at DEl inflows did surface in the United States when Japanese investments began to rise in the late $1980 \mathrm{~s}$, the main agitation has arisen from the labour unions, who have always soen the developing countrios as thenr principal foes in the game of ecomomic competition. Long opposed to 'losing jobs' to the developing countries berause multinationals move production abrad, unions in the United States have increasingly focused their attacks on the DPI geing from the North to the South as a major problem posed by the Global Age

A matching fear for jobs and wages has arisen from the increased flows of refugee and illegal immigants from the developing to the developed countries. In a world increasingly of 'borders beyond control', if I might exaggerate for effect, most developed countries are now unble to fully regulate their immigration inflows: illega! imaigration (heavily biased in composition towards the

\footnotetext{
13 I have develone this theory in scyeral recent articles, inchuding Bhagwati and Dehejia (1992). Note that the shesy relates to globalisation. not io the allegedly deteterious elfect of trade with poor contries which vaguly retlect: the conventional Pactor Pres Equalisation argument.
} 
unskilled, and hence the more resented for its feared economic impact on the real wages of the natives) has been for some time an issue in the United States and other countries. ${ }^{14}$

What is remarkable about these fears of the develored countries is that they mirror so well the fears of the developing countries almost half a century ago. At that time, the countries on the periphery feared the centre. Global integration of countries with unequal power, in that instance integration with the developed countries of greater strength, would lead to predation rather than mutual gain: skilled nationals would leave, multinationals would earn more than they would contribute, free trade would bring about perpetuation of backwardness and destroy nascent industrialisation, income distribution would grow worse, and loss of autonomy and a situation of dependencia would follow. Today, the critics of the Global Age equally maintain that continued integration of countries with unequal power, in this instance integration with the developing countries of lesser strength, would cause predation: unskilled migrants would artive, multinationals would leave to create jobs elsewhere, free trade with countries with lower labour and environmental standards would lead to deindustrialisation and loss of one's own standards, income distribution would worsen, and loss of autonomy to external forces beyond one's control and to institutions such as the WTO, where the Third World has an equal vote, God forbid, would thrcaten one's sovereignty. Indeed, the world has come full circle!

\section{PHANTOMS MORE THAN REALITY: REAL, WAGES AND JOBS}

But, just as the developing countries have surmounted their fears and learnt that global integration with the developed countries promises more than it threatens, the developed countries need to do the same today in regard to their own global integration with the developing countries. In fact, let me remind you that I plan to argue that these fears are not merely exaggerated, but also do not justify some of the proposed measures to deal with then at the international level. Let me argue this by concentrating on the question of declining wages and rising unemployment. ${ }^{15}$

\footnotetext{
${ }^{14}$ So has the explosion of refugecs, some of them leading in furn to an overload on asylurn claims in the developed countrics even as the fear has arisen that illegal immigration secks to misuse the asylum route to immigration. The refigee crisis today. as it must be called for it is no less, has been splendidly handied by Madame Ogala as the UNHCR chiet, an appointment for which Japan can properly take credit.

${ }_{15}$ Unfortunately, there is not time here to analyse other claims such as the loss of autonomy, the growing sense of atienation. etc. which are also on the Northern scene. and which I equally regard as largely exaggerated and feartul.
} 
(i) The fact: Consider, for instance, the argument that the decline in real wages of the unckilled in the United States, and altematively the rise in unemployment in Europe in the 1970 s and 1980 s, continuing into the 1990s, is a consegnence of trading with tho South. The demand for protection that follows, then, is wot the old and defunct 'pauper-labour' argument which asserted falsely' that trade between the South and the Noth could not be beneficial. Rather, it is the theoretically more defensible income-distributional argument that trade with conintries with paupers will produce paupers in one's midst, that trade with the port countries will produce more poor at home.

It is inded true that the rea! wages of the unskilled have fallen significantly in the United States during the previnus two decades. In 1973:

real hourly eamings of nom-supervisory workess measured in 1982 dollars ... were $\$ 8.55$. By 1992 they had actualy declined to $\$ 7.42$ - a level that had heen achieved in the late 1960s. Had camings increased in their tarlice pace, they wonld have risen by 40 percent to over $\$ 12 .^{\text {it }}$

The experience in Europe has generally beell similar in spiria, with the more 'inflexible' labout markets implying that the adverse impact has been on jobs rathot than on real wayes.

But the key question is whether the cause of this phenomencn is trade with the South, as anions and many politicians feel, or rapid moden information-based technical change that is increasingly substituting unskilled labour with computers that need skilled rather than unskilled labour. As always, there is debate among economists about the evidence; but the consensus today among the trade experts is that the evidence for linking rade with the South to the observed distress among the unskillod to date is hard to find. In fact, if real wages wore to fall for unskilled labour due to trade, wh the South, a necessary condition is that the goods prices of the urskilled labour-intensive goods would have to have fallen; and subsequent examination of US (and recently of Geman and Japanese) data on prices of good; shows that the opposite happened to be true in the critica! period of the 1980s. 17

Alongside this is the fear that multinationals will move out to take advantage of cheaper labour in the poor contrits as irade becomes frecr thus adding to the pressure which that trade alone, with cach nation's capital at home, brings on the real wages of the instilled. Of consec, this is also an unsubstantiated fear: but it has even greater political salience sinci the loss of jobs to trads is less easily focused on specific competing countrics and their characteristics than when a factory shuts down and opens in a foreign country instead. As it happens, I

\footnotetext{
17 Sen the many cmpitical writings of Rober Lawhene on the subject.

${ }^{17}$ 'This has been widely comeded now by those who were septical. including Ed Leamer of UCL A. The only dissident is Jetroy Sachs whose claitn to have overturned this finding is based on debatable adjustnonts wheh, even then, produce results which, while cited by the unsuspecting media. are statistically uraceptable. For an evaluation of this question. see my contribution to the forthcoming volume, edicd by Susan Collins, for the Browkings lnstitution, a think-tank in Washington DC
} 
suspect that, at least in the United States, the flow of capital is also in the wrong direction from the viewpoint of those who are gripped by such fear; because, during the 1980s, the United States received more DFI than it sent out elscwhere, both absolutely and relative to the 1950s and 1960s. Besides, if foreign savings are considered instead, the 1980s saw an influx, corresponding to the current account deficit that has bedevilled US-Japan trade relations.

But regardless of the true realities which make it difficult to assign a significant, if indeed any, role in the present predicament of the Northern unskilled workers to trade and investment in this Global Age with the developing countries, the general feeling persists in many influential quarters that trade with the developing countries is a problem and that the resulting demands on policy change have more political salience than one would care to have but would be foolish to ignore.

(ii) The demands: isolationism and intrusionism: These demands take two contrasting forms. First, there is the traditional protectionist response. Here there are those who would raise trade barriers against the developing countries: a battle cry of the erstwhile presidential candidate Pat Buchanan in the United States, who wanted an across-the-board 20 per cent tariff on import; from China and an unravelling of NAFTA. Then there are the 'moderates', who would only stop liberalising trade further with the developing countries: here we must count (Sir James Goldsmith among them, I believe) the proponents in the North of free trade areas among 'like-wage' countries as against free trade generally, as the latter would include lower-wage countries.

These protectionist pressures are not that hard for the leaders of the developed countries to resist: the advantages offered by free trade, and the ideological triumph (at least for now) of the open markets alchemy for efficiency and growth in a highly competitive world economy, make it virtually impossible for responsible leadership to embrace such isolationist ideas and attendant protectionist pseudo-solutions. But unfortunately, that is not true of the alternative response, no more desirable, than we observe on the part of some of the leading governments in the North.

This second alternative is best understood by an analogy. Faced with the prospect of a typhoon, you may move out of its range, shifting from sunny but typhoon-prone Florida to dreary but safe locales: this is the isolationist, withdrawing, protectionist response to the fears (in the developed countries) of the developing countries in the Global Age. But if you have read your Malinowski or Radeliffe Brown, you may also pray to the weather gods and get the typhoons to go elsewhere. This interventionist or intrisionist option is one that can be contemplated, as a response to the threats imagined from elsewhere, only by the economically and politically powerful countries, especially hegemons such as the United States: they can aspire to force the developing countries, by 
using a variety of punishments and inducenents, to adopt domestic institutional and policy changes so that the competitive threat is moderated.

This is how we nust intereset the chorus of demands that have spread in the US and Europe for inclusion of Envirommenta: and Labour Standards in the W'TO, regaining that either the be noved up in the developing countries or that the developed contrics should be allowed to countervail the 'implied subsidy' represented by trese lower standarts.

Several factors, including moral ancs, undoubiedly contribute to the encrgenes of one or more of these 'fait trade' demands. But a principal one among them sts surely the desire to raise, in one way or another, the costs of podvetion of your rivals abroad: and what is more easy to do than to say that they are deiving arvatage by having lower enwronmenta! and labour standards, and therefore free trade with them amounts to 'unfair trade'? 'This complaint, and atendant agitation for penalising these foreign firms with import taxes if theit comptries do not raise their standards towards one's own, then has the advantage that, either you whl be able to get yotir rivals' costs up and reduce the pressure of their competition by forcing then to raise their environmental and labour standards, or, if they do not to so, you will got protection against them as trade bariers are laised agurst the contming unfaimess of competition. This agitation therefore offers a foolproof neihod of meeting your foreign rivals' competition: it therefore also accounts for its popularity.

Biit let no argue that these domand: are being properly resisted by the developing countries and are being inappropriately accommodated by some of the govemments in the developed countries, as in the recent pressures emanating from the US. and France in particular, in favour of a Social Clause at the WTO.

\section{INTRESIONISM: EWVIRONMEN'TAL AND LABOUR STANDARDS}

Thes demands are inwisely tecreating the North-South divide. To understand the foily of thes to developed countres, and the dargers they pose to the deweloping countres and to the wordd trading regime, let me now address in succession the parald but still contrasting issues of eco-dumping (in subsections $a-c)$ and of the Social Clause (in subsction $d$ ) at the WTO

\section{a. The legitinacy of Diversity and the Folly of Eco-duniping Demands}

If we are dealing with 'globa' emvironmental problems when there are transborder extemultes. as with the global warning and ozone layer problems, it is now recognised thin we need global solutons which avoid free-rider problems and include ponshments for defection. The disagrements among countries that 
universally accept the need for such solutions arise only from differences in their views of what is a 'fair' allocation of the burden of pollution avoidance, especially as there is an understandable tendency on the part of the worst offenders, the developed countries, to shift the burden of adjustinent on to the developing countries: a tendency clear in the solutions being devised for dealing with the global warming problem.

The eco-dumping allegation, on the other hand extends plainly to what economists call 'domestic' environmental problems: as when effluents are discharged into a lake or a river that is entirely within a nation's own borders and there are no transborder spillovers into other jurisdictions.

In this latter set of domestic pollution cases, economists would generally expect to find diversity rather than uniformity of environmental standards in the same industry in different countries. I will call these Cross-country Intia-industry (CCII) differences in standards, iypically iii the shape of pollution tax rates. This diversity of CCII standards will follow from differences in trade-offs between aggregate pollution and income at different levels of income, as when richer Americans prefer to save dolphins from purse-seine nets, whereas pooren Mexicans prefer to put peorle first and want to raise the productivity of fishing, and hence accelerate the amelioration of Mexican poverty by using such nets. Again, countries will have natural differences in the priorities attached to which kind of pollution to atack, arising from differences of historical and other circumstances: Mexicans will want to worry more about clean water, as dysentery is a greater problem, than Americans who will want to attach greater prionty to spending pollution dollais on clean air. Differences in techiriological know how and in endowments can also lead to CCil diversity in pollution tax rates.

The notion, therefore, that the diversity of CCII pollution standards/taxes is illegitimate and constitutes 'unfair trade' or 'unfair competition', to be eliminated or countervailed by eco-dumping duties, is itself illegitimate. It is incorrect, indeed illogical, to assert that competing with foreign firms that do not bear equal pollution tax burdens is unfair. I would add three more observations:

- We should recognise that if we lose competitive advaniage because we put a larger negative value on a certain kind of pollution whereas others do not, it is simply the flip side of the differential valuations. To object to that implication of the differential valuation is to object to the differential valuation itsclf, and hence to our own larger negative valuation.

- Besides, it is woth noting that the attribution of competitive disadvantage to differential pollution tax burdens in the fashion of CCII comparisons for individual industries confuses absolute with comparative advantage. Thus, for instance, in a two-industry world, if both industries abrodu have lower pollution tax rates than at hoine, both will not contract at home. Rather, the 
industry with the comparatively higher tax rate will. The noise that each industry makes on the basis of CCil comparisons, aggregated to total noise by al! industries, is then likcly to exaggerate serionsly the effect of different envionmental valuations and CCII differences on the competitiveness of irdustries in higher-standards nations.

- But the legitimacy of the diversity may be suspes if the governments that are making the decisions on pollution tax rates are unrepresentative. Cicarly, one connot atiribute such legitimay to the Soviet bloc governucnts intich, in fact, polluted wantonly and whose citizets had no voice But fortinaty democracy has broken out alunost everywhere: just a fer combies, either the strageders from the commurist era (China, Nomh Korea and Cubal or the non-jdeological one-loadsr or one-party states (Iraq and Syria), now lie wholly outside the democratic pale.

\section{b. An Unjustified Foor of the 'Rroe to the Botion'}

Ooe more wormy needs to be laid to rest if the demands for upwaid hamonisation of standards, or eco-dumping duties in licu thereof, are to be effectively distnissed. This is the wony that free trade with countries with lower standards will force down one's higher standards. The most potent of these worries arses from the fear that 'capital and jobs' will move to countries with lower standards, tiagering a race to the botom (or, nore accutately, a race towards the homom). So the solution would then lic in coordinating the standardsetting anong the nations sighged in freer trade and investment. In turn, ihis may (but is mos walkely to) require hamonisation among countries to the higher standards (though. even then, not necessarily to thuse in place), or perhaps there might be improvement in welfare from simply setting minimum floors to the standards.

Unlike the aronment just rejected that dismisses diversity of standards as illegitmate and therefore mfair per se, this is undoubtedly a theoretically valid argument. The key question for policy, however, is whether the empirical evidence shows, as reguirod by the argument, that: first, capital is in fact responsive to the differences in erviromental stardards; and second, that different countiesturtictions actually play the game of competitive lowering of standarts to attiant capital. Without both these phenomena holding in a significant fashion in reality, the 'race to the bottom' would be a theoretical curiosity.

As it hippens, systematic evidense is available for the former proposition alone, but the rinding is that the proposition is not supported by the studies to date: there is very weak evidence at best in favour of interiurisdictional mobility in response to CCII differences in environmental standards. There are, in fact, 
many ways to explain this lack of responsiveness: differences in standards may not be significant and are outweighed by other factors that affect locational decisions; exploiting differences in standards may not be a good strategy relative to not exploiting them; and lower standards may even paradoxically repel, instead of attracting, DFI.

While we do not have similar evidence on the latter proposition, it is hardly likely that, as a systematic tendency, countries would actually be lowering environmental standards in order to attract capita!. As it happens, countrics, and even state governments in federal countries (e.g. President Bill Clinton when Governor of Arkansas), typically play the game of attracting capital to their jurisdictions: but this game is almost universally played not by inviting firms to pollute freely, but instead through tax breaks and holidays, land grants at throwaway prices, etc., most likely resulting in a 'race to the botiom' on business tax rates which wind up below their optimal levels! It is therefore not surprising that there is little systematic evidence of governments lowering environimental standards in order to attract scarce capital. Contrary to the fears of the environmental groups, the race to the bottom on environmental standards therefore seems to be an unlikely phenomenon in the real world.

I would conclude, then, that both the 'unfair trade' and the 'race to the bottom' arguments for harmonising CCII standards, or else legalising eco dumping duties at the WTO, are therefore lacking in rationale: the former is theoretically illogical and the latter is empirically unsupported. In addition, such WTO legalisation of eco-dumping will facilitate protectionism without doubt. Anti-dumping processes have become the favoured tool of protectionists today. Is there any doubt that their extension to eco-dumping (and equally to social dumping), where the 'implied subsidy' through lower standards must inevitably be 'constructed' by national agencies such as the Environmental Protection Agency in the same jurisdiction as the complainant industry, will lead to the same results even more surely?

The 'fixing' of the WTO for environmentai issues, therefore, should not proceed along the lines of legitimating eco-dumping. However, the political salience of such demands remains a major problem. One may well then ask: are there any 'sccond-best' approaches, short of the eco-dumping and CCII harmonisation proposals, that may address some of the political concerns at least economic cost?

c. A Proposal to Extend Domestic Standards in High Standard Countries to their Firms in Low Standsrd Countries. Uniloterally or Preferably through an OECD Code

The political salience of the harmful demands for eco-dumping duties and CCII harmonisation is greatest when plants are closed by one's own multinationals and shifted to other countries. The actual shifting of location. 
and the associated loss of johs in that plant, greatly magnify the fear of the race to the botton' and the 'impossitility' of competing against low standard conntrios. Similarly, when investment by one's own firms is seen to go to specific countres which hapren to have lower standards, the resentment gets to be focused readiy agunst those countries and thetr standards. However, when jobs are lost simply becasse of irade competition, it is much harder to locate one's resenment and frar on one specific foreign country and its poicies as a source of Whair competition. Hence, a scond best proposal could well be to address this particular fear towever unfounded and often illogical, of outnigration of plants aret investment by ore's firms abroad to low standard countries.

The proposal that I would tike to make, most appropriately in Johannesburg, is to adapt the so-called Sullivan Principles approach to the problem at hand. Under Suliven, US tirms in South Africa mero uged to adopt US practices, not the South Afrom aparthoid way, in their merations. If this principle that LS firms in Mexico be subject to US enviommental policies were adopted by US legislation, then wonld automatically renove whatever incontive there was to imove beczise of envirommental burden differences.

This proposal that one's fims abroad behave as if they wete at home can either be legislated unilaterally by any high standard country or by a multilateral binding irouty amnog different high standard countries. Again, it may be reduced to an exhotation. just as the Sullivan Principles were, by single countries in

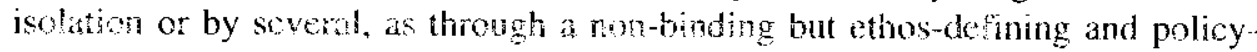
encouraging OECD Code.

The disalvantage of this proposal, of course, is that it does violate the diversity-is-tegttmate rule (whose desiability was argued by me). Investment flows, like inesment of cne's own furds, and production and trade therefrom, should refiect this diversity. It herefore reduces the efficiency gains from a freer tow of cross country investments soday. But if envirommental tax burden differences are not all that differen, or do not figute prominently in firms. locational deciston as the empirical literature seems to stress, the efficiency costs of this proposal could also be minimal, while the gains in allaying fears and therefore moderating the demand for bad proposals conld be very large indeed.

Yet another ofjection may focus on intra-OECD differences in high standards. Since there are differences amony the OECO countries in CCII environmental tax burdens in spreific industes for specific polbtion, this proposal would lead to 'horizontal ineyuty' among the OECD firms in third countries. If the British burden is higher than the French, British firms would face a bigger burden in Mexico thin the Fronch fims. But such differences already exist among fims abroad since tax poctices among the OFCD countries on taxation of those firms are not hamonised in many respects. Interestingly, the problem of horizontal equity has come up also in relation to the demands of the poor countries (that often find is dificult to enforce impont restrictions effectively), that the domestic 
restrictions on hazardous products be automatically extended to exports by every country. That would put firms in the countries with greater restrictions at an economic disadvantage. But agreement has now been reached to disregard the problem.

Other problems may arise: monitoring of one's firms in a foreign country may be difficult; and the countries with lower standards may object on grounds of 'national sovereigniy'. Neither argument seems compelling. It is unlikely that a developing country would object to foreign firms doing better by its citizens in regard to environmental standards. Equally, it would then assist in monitoring the foreign firms.

If I may be cynical, this eminently reasonable proposal, which I made at the time of NAFTA in an article in the New York Times, was not received with enthusiasm by the corporate sector, and hence by either the US administration or the Congress, because the well-guarded little secret of the multinationals is that their demands on their governments, and hence on what they want included in the WTO, as with TRIMs and now the more ambitious Multilateral Agreement on Investment, concern the removal of impediments to their expansion, not the imposition of restrictions on their freedom to manoeuvre.

\section{d. The Question of Labour Standards and the Social Clause}

The question of labour standards, and making them into prerequisites for market access by introducing a Social Clause in the WTO, has both parallels and contrasts to the environmental questions. The contrast is that labour standards have nothing equivalent to transborder environmental externalities. One's labour standards are purely domestic in scope; in that regard, the demands for 'social dumping' for lower labour standards that paraliel the demands for eco-dumping have the same rationale, and hence must be rejected for the same reasons.

But a different aspect to the whole question results from the fact that labour standards, unlike most environmental standards, are seen in moral terms. Thus, for example, central to much thinking today on the question of the Social Clause is the notion that competitive advantage can sometimes be morally 'illegitimate'. In particular, it is argued that if labour standards elsewhere are different and unacceptable morally, then the resulting competition is morally illegitimate and 'unfair'.

Now when this argument is made about a practice such as slavery, and its other forms such as bonded labour, including the abhorrent practices of mortgaging one's children to de facto servitude to employers, and of abusively exploiting prisoners in the labour camps in the gulag, there will be nearly universal agreement that if such slavery produces competitive advantage, that advantage is illegitimate and ought to be rejected as posing unfair competition to one's workers in competing industries. 
The moral argunent, however, may not be merely to consider such slaverybased congetition as unfuir to our industrics and workers. It may also be that we do not wish to profit from such irad: we will not sup with the devil even though we miss a free moal. Or it may be a consequentialist moral argument that we wish to punist others whe permit such slavery and, by denying them trade in such slavery-produced goods, we seek to induce them to change such slavery. ${ }^{18}$ The insertion of a Sacial Clause for labour standards in the WTO can then be seen as a way of legtinating a compelling and unversally accepted moral exception to the otherwise sensible CATT rute that probibis the suspension of a contracting party's trading rights concerning a product simply on the ground that another contracting party objects to the process by which that product is produced.

The real problem with the argument, however, is that universally condemned practices such as slavery are indeed rare. The reality is that diversity of labour pracices and stantants is widesprend in practice, and for the most part reflects not aecessarity verality and wickedness, but rather diversity of cultural values, conomic conditions, and analytical heliefs and theories concerning the economic (and therefore mowly consequences of specific labour standards. The notion that labour standards can be universaliesd, like human rights such as liberty and habea corpus, simply by calling then 'labour rights', ignores the fact that this easy equation between culture-specific labour standards and universal human rights will have a difficult time surviving deeper scrutiny.

1 might minstrate the fundamental difficulties we face by taking the United States (xince it is a pincipal proponent of the Social Clause) and demonstrating immediately that the US logic on the question can lead the US itself into a legitimate denand for a widesprear and sustained suspension of its own trading rights if a social Clanse were establshed.

Thus, for instance, worker participation in decision making on the plant, a moasme of trie economic derrecracy for both whonised and non-umionised latures that is surely much more pertirent than the mere unionisation of labour, is far mote widespread in Europe than in North America: would we then condemn Nonh America to denial of trathe rights by the Europeans? Migrant labour is again ill-ireated to the level of bratality and slavery in US agriculture due to grossly inadicuate and cormp: enforcement, if investigative shows on US telovision are a guide; does this mean that other nations should prohibit the impon of US agriculturat products? Sweatshops exploiting female immigrants with bong hous and below minimm wages are endemic in the lextile industry, as documented amply by several civil liberties groaps and now appreciated widely becanse of the discovery of an establishment in Californa that employed virtual slaves, and the subsequent admissiou by Labour Secretary Reich that monitoring and enforcement were appallingly weak and would remain so because of lack of

"I have considerad the alternative moral argments in Bhagwati and Hudec (1996, Ch. 1, Vol. 1). 
funds: should the right of the US to export textiles then be suspended by other countries as much as the US seeks a Social Clause to suspend the imports of textiles made by child labour?

Even the right to organise trade unions may be considered inadequate in the US if we go by 'results', as the US favours in judging Japan: only about 12 per cent of the US labour force in the private sector today is unionised. Indeed, it is no secret, except to those who prefer to think that labour standards are inadeguate only in developing countries, that unions are actively discouraged in several ways in the United States. Strikes are also circumscribed. Indeed, in essential industries they are restricted: but the definition of such industries also reflects economic structure and political realities, making each country's definition only culture-specific and hence open to objection by others. Should other countries then have suspended US flights because President Reagan had broken the air traffic controllers' strike?

Even the question of child labour is not an easy one. The use of child labour as such is surely not the issue. Few children grow up, even in the US, without working as babysitters or delivering newspapers; many are even paid by parents for housework in the home. The pertinent social question, familiar to anyone with even a nodding acquaintance with Chadwick, Engels and Dickens, and the appalling conditions afflicting children at work in England's factories in the early Industrial Revolution, is rather whether children at work are protected from hazardous and oppressive working conditions.

Whether child labour should be altogether prohibited in a poor country is a matter on which views legitimately differ. Many feel that children's work is unavoidable in the face of poverty and that the alternative to it is starvation, which is a greater calamity; and that eliminating child labour would then be like voting to eliminate abortion without worrying about the needs of the children that are then born.

'Then again, insisting on the 'positive rights'-related right to unionise to demand higher wages, for instance, as against the 'negative rights'-related right of freedom to associate for political activity, for example, may also be morally obtuse. In practice, such a right could imply higher wages for the 'insiders' who have jobs, at the expense of the unemployed 'outsiders'. Besides, the unions in developing countries with large populations and much poverty are likely to be in the urban industrial activities, with the industrial proletariat among the better-off sections of the population, whereas the real poverty is among the non-unionised landless labour. Raising the wages of the former will generally hurt, in the opinion of many developing country economists, the prospects of rapid accumulation and growth which alone can pull more of the landless labour eventually into gainful employment. If so, the imposition of the culture-specific developed country union views on poor countries about the rights of unions to push for higher wages will resolve current equity and intergenerational equity problems in ways that are then morally unacceptable to these countries. 
(i) The Social Clause - a bstidea: Ono is then led to conclude that the idea of the Social Claise in the WTO is gencrally rooted in an ill-considered rejection of the general legitmacy of diversity of labour standards and practices across countries. The dhegeu claim for the universality of labour standards is (except for a fiw rart cases whoh as slavery, and its close variants such as labour in bondage and in its gulag) gencrally umpersuasive. The developing countries cannot, then, be blamed for worying that the recent escalation of support for such a clause in the WTO in the United States and Fance, among the leading OECD countries. derives instead from the desire of labour unims to protect their jobs by protecting the industris that face competition from the poor countries. They fear that moral argumens ate produced to justify restrictions on such trade since they are so effective in the public domain. In shor 'blue protectionism' is breaking rut, masking behind a moral face

Indered, this fenful conclusion is reinforced by the fact that mone of the major OECD countries pusting for such a Social Clause expect to be the defendants instead of the plantifs in Social Clause-generated trade access cases. On the one hand, the standards (suct as prohitition of chitd labour) to be included in the Social Clave to date art invariably presented as those that the developing countries are suly of violating, everi when some transgressions thereof are to be feund in the developed cointries themaelves. Thus, according to a repon in $T h e$ Finarial Times, a standard exampls used by the labour movement to garner support for better safety standards is a disastrous fire in a toy factory in Thailand where many died tragkally because exits were shut and unusable. Yet when I read this report. I recalled ar example just like this (but far more disconcerting when I noted that the fatalitics occurred in the richest conntry in the world) about a chicken plant in North Carolina where the exits were also closed for the sane reasm. Yet the focus of intemational agitation has been on the poor, not the rich, country.

At the same time, I must say that the argument that the Social Clause should contain 'core' standards sounds fine, nntil you realise that this is also tantamount to a chojee of standards for attention and sanctions at the WTO that is also clearly biased against the poor comtries, ii the sense that none of the problems where many of the developed countries themselvas would be more likely to be found in significans violation --.. such as worker participation ia management, union rights, rights of nigrants and immigrants ...- are meant to be included in the Social Clause. Symmetry of obligations simply does not exist in the Social Clause, as contemplatod currently, in tamms of the coverage of the standards.

This theme may be pursued further. The choice of the WTO as the repository of a Social Clause, stacked against the develoning countries, is also a way of reducing the probability of being a defendant. Tinis is because the standing to bring cases at the WTO lies with the member governments not with NGOs as in the public interest litigation in lndia or in the case of human rights if a nation has 
signed (as the United States has not done) the Optional Protocol on the International Covenant of Civil and Political Rights. India and Egypt, for instance, may be expected to be bamboozled by threats and inducements, political and economic, by major powers into not pursuing Social Clause-led cases against them; but the NGOs would not so easity back away from such a scrap. If indeed the demands are being truly inspired by a moral viewpoint that genuinely seeks symmetric universal rights and their enforcement, the choice of the WTO as the institution of choice for sanctions is hardly credible

Indeed, both the choice of standards to be included in the Social Clause, and the choice of the institution where the Social Clause will be situated, cannot but leave serious analysts in the developing countries convinced that the movement is a prime example of what I called Intrusionism, inspired by the desire to moderate competition from the developing countries by raising their costs of production. This view is further reinforced when the unions allied to these demands are often seen to be those in industrics directly threatened by such competition, or when the morality underlying the demands for a Social Clause is couched in terms of a universalist language that asserts transborder moral concerns by groups that equally support immigration controls that deny the universalism they assert.

(ii) If not a Social Clause, what else? If this analysis is correct, then the idea of a Social Clause in the WTO is not appealing; and the developing countries' opposition to its enactment is totally reasonable. We would not be justified, then, in condemning their objections aind unwillingness to go along with such demands as depravity and 'rejectionism'.

But if a Social Clause does not make good sense, is everything lost for those in both developed and developing countries who genuinely wish to advance their views of what are 'good' labour standards in a decent society? Evidently not. It is surely open to them to use other instrumentalities such as non-goveminental organisation (NGO)-led educational activities to secure a consensus in favour of their positions. In fact, if your ideas are good, they should spread without coercion. The Spanish Inquisition should not be necessary to spread Christianity; indeed, the Pope has no troops. Mahatma Gandhi's splendid idea of non-violent agitation spiead and was picked up by Martin Luther King, and finds strong resonance in the practice and precepts of President Mandela, not because he worked on the Indian government to threaten retribution against others; it happened to be just morally compelling.

I would add that one also has the possibility of recourse to private boycotts, available under national and international law; they are an occasionally effective instrument. ${ }^{19}$ They constitute a well-recognised method of protest and consensus creation in favour of one's moral positions.

19 Though, here also, I must add that inany NGOs and citizens in the developing countries are
rightly concerned by the asymmetric power that can be exerted by private boycotts in countries that
are economically more substantial and politically more powerlul, thus lending greater weight to the 
Where, moreover, a nation has unmarketable and culture-specific moral views $\mathrm{s}^{20}$ on the protuction and import of cortain products, and is under domestic political pressure to go alone with official saspension of such imports, it is worth strossing that there is nothing in the current international regime to prevent it from doing so. It can simply suspent the trade of another country and 'pay' for it by making rade concessions, or it can put up with matching retaliation by the other country in the form of its own withdraval of market access to the punishing coumtry The latter is, in effect, what the EU did over their politically necessary suspension of the hormone-fed beef trade and the subsequent retaliation by Ambassador Carla Hills of the United States.

\section{THE GLOBAL. AGE: TRANSCENDING FEARS TO CONSTRUCT A. NEW ARCHITECTURE}

The sew intemational architecture that we must build to secure the gains from the Glowel Age must not be formded on fauly foundations inspired by exaggerated fears. It must also not be one that begins by creating a NorthSouth divide when we have just managed to put such dissentions behind us in a common vision reflecting the universalism of both economics and politics that I drew your attention to. What vision, then, should we embrace? Ox perhaps, if I may recall Raul Pretisch at the end as I did at the beginning, where would he, simultaneossly a visionary and a buider, have led us at this historic juncture?

(i) We need to reject the folly of including a Social Clause and eco-dumping varioties of tade and environmental agendas into the xorld trading regirne: the WTO would sirely be handicapped, and the developing countries hamed, by sucti moasures.

(ii) Instead, recognition of the important role of NGOs, careful design of labelling approaches, and encouragement of improved environmental and labour practices by appropriate institutions weh as UNEP, UNICFF and the ILO, are among the proper ways to bring these great tasks to attention and fruition today.

(iii) Morover, instead of moving the world into a foolish straitjacket of deep integratios' - a shallow concept when is comes to the Social Clause,

\footnotetext{
moral concerns of the citizens of the suong as against those of the weak aations. So the time may well havt come to examine whether organised piivate hoyonts should be pemitted without restrinit when exerted against weakee, forcign nations.

21" Are the Anerican love for dolphins, the Indian respect for cows and the English affection for dogs witrosalisable by moral suasion? They are rarely grounded in basic beliefs in animal rights, but sem to refect notions such as 'culeness' (dolphins fook so tuman. look at their pretly snouts) or 'loyalty' (a dog is man's best friend) which are suraly culture-specific
} 
environmental tax burden hamonisation. ets: - - and forcing it on the WTO and the developing countries, to whose disadvantage it must work, it is better to finish the task of creating a world of free trade, an essential component of the Global Age that still remains a job unfinished.

(iv) This task is all the more important as the trading system has now been afflicted by a huge and increasing proliferation of free trade areas which are better called by their true name: Preferential Trading Arrangements (PTAs). These PTAs now criss-cross the world economy, creating a 'spaghetti bowl' phenomenon of trade tariffs and NTBs that depend on where products come from: numerous rates apply in the EU and US alone, depending on source, with 'rules of origin': producing a maze messing up the international division of labour in the Global Age.

These PTAs are politically driven: no politician is happy unless he has put his signature on at least one of them. It gives them a place in the suin and, while going preferential, you can still pretend that you are for free trade since no one in the media understands the distinction. We economists now have a CNN theory of regionalism or PTAs: you can get on to world television through an APEC or a Mercosur summit which you cannot at Geneva at the WTO!

So the only way to kill this growing maze of preferences is not through ingenious changes in Article XXIV at the GATT/WTO which sanctions PTAs, or by prohibiting PTAs which simply cannot be suppressed when the politica! demand for them is so overwhelming, but through going to worldwide free trade (which effectively kills the preferences since a preference relative to zero is zero).

(v) The nations of the world must unite behind such a vision and such a target: worldwide free trade by, say, the year 2010. Mr Renato Ruggiero and Mr Rubens Ricupero can be natural allies in propagating such a target: for it would galvanise both WTO and UNCTAD. Both institutions are at a critical defining moment in their history, the WTO beginning to create it and UNCTAD struggling to survive it.

Mr Ruggiero's task will be to bring the reluctant United States on board: cajoling it away from its current folly of embracing the Social Clause and rejecting an activist further-freeing-of-trade-role for the WTO in the matter of setting its new agenda. ${ }^{21}$ On the other hand. remembering that the era of exceptionalism is over, Mr Ricupero must unhesitatingly bring the developing countries on board behind such a target.

\footnotetext{
${ }_{21}$ Indeed, at the QUAD trade talks in Kobe some time ago, the United States managed to bamboozle Canada and Japan into acquiescence on going to the Deccmber 1996 Ministerial of the Wro with the demand that the Social Clause be included on that agenda. When a grea power is set on a task, no matter how harmful, it is hard to offer continued resistance. I would predict (and hope), however, that this persistence by the United State; will produce a major confrontation in Singapore.
} 
I am afratd that, ironically, Mr Ruggiero's task is likely to be the more difricult since the US, and inded France, are in the throes of Intrasionism inspired by the phantom fears of the Glosal Age. By contast, Mr Ricupero should find his task mish easier as the developing countries now find in the Global Age the virtues that they could not see in the eamer years. But it is my fond hope that the wo will be able $t 5$ lead, hand in hard, in shared partnership the nations of the world into a truly Golden Age with worldwide free trade. Indeed, one could not hope to find better denteshop than what they offer. After all, by a rewarkable coincidence, the names of both these men can he initialised to RR: a symbol of exceptional quality to us in the Somer colonics of Great Britain, whic RR stood, of course, for Rolls Royce!

\section{REFERENCES}

Bhagwat, J. (1995), 'Democracy and Development: New Thinking on an Old Question', 1994 Raj oandhi Memorial Lecume publishet in a slightly abbreviated version in the Journal of Denway (October 1995).

Bhagwati, J. (1996), "The "Mircle" that Did Happen: East Asian Growth in Comparative Perppective", keyonte sect to a Cornell Universily Conference on Easi Asia imimeo, Economies Deputment, Columbia Univcrsity, May).

Bhagmat. J. and V. Dehejia (1992) in J. Bhagwati and M. Kosters (eds), Trade and Wages: lavelling Down?., (American Enterprise Institute, Washington, DC).

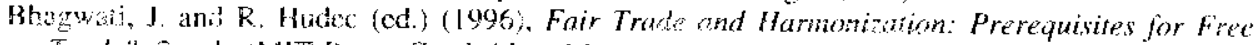
Trade?" I vols (MIT Press, Carbidige, Mass).

Gavin. M. and D. Rodrik (1995), 'The World Bank in Historical Perspective', American Economic. Review (May).

Irwin. D. (1996), "The United States in a Ghobal Economy? A Century's Perspctive'. American Economic Review (May). 
Copyright of World Economy is the property of Wiley-Blackwell and its content may not be copied or emailed to multiple sites or posted to a listserv without the copyright holder's express written permission. However, users may print, download, or email articles for individual use. 